\title{
R2P and the Pluralist Norm-shapers
}

\section{Mikelli Marzzini L. A. Ribeiro*}

\begin{abstract}
Responsibility to Protect (R2P) brought about new challenges for research on norms in International Relations, mainly due to the actions of emerging powers. These states have exhibited complex behaviour towards norms. Rather than classifying them as simple norm-rejecters or norm-takers, current literature on norms in International Relations has classified them as normshapers. In their behaviour, emerging powers seek to shape the norm from various angles. In this sense, the need arises to theoretically frame these types of engagement. This essay aims to analyse the action of normative shapers through the lens of the English School of International Relations, combined with constructivism. After presenting the norm-shapers and characterising them theoretically, a new concept is introduced, called pluralist norm-shapers.
\end{abstract}

Keywords: Responsibility to Protect; English School; emerging powers; norm-shapers; pluralism.

\section{Introduction}

With the end of the Cold War, the promotion of ideas that sought to reinforce international responsibility in humanitarian crises and implement the notion of conditional sovereignty emerged in various ways. One of the most critical ways was through the concept of the Responsibility to Protect (R2P). In 2001, the International Commission on Intervention and State Sovereignty (ICISS), with the assistance of the Canadian government, elaborated this new normative understanding, which argued that state sovereignty also implies responsibility.

Despite the scepticism from several global South states, R2P resisted and evolved institutionally. Secretary-General Kofi Annan's commitment was decisive. He published documents and reports that carried out this idea directly or indirectly. These documents provided the basis for its institutionalisation as a UN political norm in 2005 at the World Summit Outcome (UN 2005).

R2P has brought new challenges to the scholarship on norms in International Relations (IR), especially with regard to the emerging powers. These states have exhibited complex behaviour towards the concept since its inception. The most recent literature on norms in IR often assumes that they adopt a stance of constructive contestation: they seek to adjust R2P so that it fits into their own visions about the international system (see

* Federal University of Pernambuco (UFPE), Recife-PE, Brazil; mik_lucas@hotmail.com. ORCID iD 00000002-6025-6310. 
Pu 2012; Welsh 2014; Job and Shesterinina 2014; Rotmann, Kurtz and Brockmeier 2014). This happens even by offering their own specific proposals, such as Responsibility while Protecting (RwP), launched by Brazil in 2011, and the Chinese concept of Responsible Protection (2012).

Given this particular behaviour, the normative scholarship focused on explaining compliance that emerged in the 1990s proved to be an inadequate framework for analysis (see Katzenstein et al 1996; Finnemore and Sikkink 1998). Instead of investigating whether states are norm-takers or norm-rejecters, scholars who investigate R2P's normative issues started to devote their attention to a different kind of approach. They began to concentrate on the dynamics under which states engage to shape international norms $(\mathrm{Pu}$ 2012).

For this new scholarship, emerging powers adopt a restraining behaviour. Even though they recognise the impossibility of eliminating the norm, these states estimate that it is possible to shape it towards a more conservative direction. They are perceived as seeking to limit R2P from various angles so that it conforms to Westphalian norms, especially institutions such as sovereignty and non-intervention. This attitude brings the need to theoretically frame this type of action.

According to the English School of IR, a society of states that seeks to sustain the basic norms of the Westphalian system is identified as a pluralist international society (Jackson 2000; Buzan 2004) - opposed to solidarist (Hurrell 2007; Wheeler 2000; Linklater and Suganami 2006). Although the pluralist conception has been theorised to analyse the international structure, the most recent literature that deals with the English School's assumptions started to apply it equally to categorise actors. In this sense, there are not only pluralist societies, but also pluralist states. This sort of state is engaged in making the international society consistent with the fundamental norms of pluralism (Allison 2013, 2015).

Thus, this paper analyses the norm-shaper's behaviour around R2P through the lens of the English School of IR. It associates aspects of the scholarship about the norm with pluralist elements. The aim is to offer an understanding of this phenomenon from the School perspective. The essay also uses a constructivist framework as a complementary approach to advance the analysis of social norms and states' identities. The dialogue between these two different theories is another important contribution of the work.

The article is organised as follows. The first section presents the literature on normshapers with respect to R2P. The second section deals with the types of norm-shapers. The third shows how the engagement of states with regard to R2P can be read from the pluralist's point of view. The fourth section briefly examines the case of China in order to illustrate how pluralism is reflected in the states' positions. At the end, a new theoretical concept, called pluralist norm-shapers, is introduced.

\section{Who are the norm-shapers?}

In the current international order, normative socialisation is often seen as a unidirectional process. Usually, international norms are created by Western powers, which spread it to non-Western states ( $\mathrm{Pu}$ 2012). The non-Western states normally have only two options: 
take or reject the new norms. Most recently, however, this dynamic seems to have been challenged by a group of non-Western states that have acquired more means (power) to act in the international realm: the emerging powers. This is particularly true in matters relating to collective security and international governance, central aspects to the issues surrounding R2P (Hunt 2016: 2).

This idea is presented by Pu Xiaoyu (2012) in an article titled 'Socialisation as a twoway process: Emerging powers and the diffusion of international norms.' The author argues that the global power shift has made emerging powers more inclined to participate in international governance. This attitude can be particularly noted with respect to the normative aspects of international structure. As the power of the emerging powers grows, they tend to avoid passively accepting the normative preferences of the Western powers ( $\mathrm{Pu}$ 2012: 356). This raises the need to consider the role of agency in the studies of norms.

According to $\mathrm{Pu}$ (2012: 347), it is possible to identify two movements coming from opposite directions: on the one hand, emerging powers are pressured by the international structure $^{1}$, on the other hand, they try to influence the same structure. He calls it a twoway process. Hence, instead of just norm-leaders (the ones who promote international norms) or norm-takers, emerging powers are considered norm-shapers.

$\mathrm{Pu}$ (2012) argues that issues related to humanitarian intervention and R2P are illustrative matters to understand the behaviour of emerging powers as norm-shapers. Brazil and China are clear examples, considering their continuous participation in the R2P debates, as well as the proposals they have made to shape the norm ( $\mathrm{RwP}$ and RP, respectively). According to Hunt, these states 'have in fact tried to influence and shape normative development through localization of their substance, meaning and parameters' (Hunt 2016: 14).

Jennifer Welsh points out that a high degree of contestation comes mainly from two aspects of disagreements: over operationalisation and over part of its content. International institutionalisation sometimes leads to a new stage of discussion that usually involves debates about the desirability and the normative scope, which eventually affects implementation and often creates divergences regarding its meaning (Welsh 2013: 379).

Thus, R2P is a typical case of what has been called 'non-linear norm dynamics' in an international society marked by complexity (Hunt 2016). Because of this, recent scholarship has been focusing on investigating emerging powers' contestation and their norm-shaping behaviour with regard to the norm (Gardner 2015). In particular, they seek to demonstrate that $\mathrm{R} 2 \mathrm{P}$ is still in formation, so it is not a completely settled norm. Although there is a consensus around 'soft' parts of the norm, there are significant controversies that other components are taking into account - notably those dealing with the use of force (Jegat 2016).

Some works analyse the emerging powers' norm-shaping behaviour in a broader sense (Thakur 2013; Pu 2012; Gardner 2015; Negron-Gonzales and Contarino 2014). Others concentrate on group concertation, as in the case of BRICS (Stuenkel 2014). There is also comparative analysis (Job 2016) or, more specifically, case studies. Notably, research focusing on Brazil and China, due to the proposals they have launched, is aiming at giving a precise meaning to the norm (Benner 2013; Garwood-Gowers 2015; Stefan 2016; Tourinho, Stuenkel and Brockmeier 2016; Kenkel and Stefan 2016). For this literature, 'both 
China's RP and Brazil's RwP proposals are recent illustrations of the increasing willingness of emerging powers to play a role as norm shapers' (Garwood-Gowers 2015: 320).

Brazil, for instance, is seen as a normative entrepreneur (Benner 2013). By launching RwP, Brazilian diplomacy made constructive criticism focusing on improving the criteria for norm implementation (Tourinho, Stuenkel and Brockmeier 2016: 143). It was considered a 'perfect illustration of what a "norm shaper" entails, especially when applied to a non-Western context' (Stefan 2016: 108).

As for China, norm scholarship in IR argues that it 'assumed a more proactive role in this period as a "norm shaper", that is, an actor looking to alter objectionable components of R2P to bring them into line with Chinese norms and interpretations of appropriate international action' (Job 2016: 897). China's stance on the development of R2P is perceived as an action to delay its consolidation process (Zheng 2016: 689). This attitude would be reinforced by the contributions of Chinese scholarship - which offers 'constructive suggestions' to adjust the norm. This kind of engagement is treated as evidence of China's willingness 'to participate in the norm-building of R2P' (Liu and Zhang 2014: 423).

\section{What kind of norm-shapers?}

By assuming that emerging powers are norm-shapers, a second inquiry arises: what kind of norm-shapers are they? Scholarship on norms in IR is also looking for answers to this question. Usually, many opinions rest on the importance that sovereignty and the norms derived from this institution have for these actors. Brian Job (2016: 893), for instance, argues that emerging powers, such as Brazil, China, and India,

$[\mathrm{P}]$ roceed from an appreciation of the principles and norms that have shaped these countries' history. Their international relations are grounded on key foundational principles reflecting their legacies of colonial domination, their concern to protect their territorial integrity and political independence, and their inherent distrust of Western 'imperialist' tendencies. Thus, [...] the perceived dangers of separatist movements and of foreign intervention have cemented for each a determined reinforcement of Westphalian norms of sovereignty and territoriality.

For $\mathrm{Pu}$ (2012: 358), emerging powers act to establish their 'normative preferences for sovereignty', which have 'significant impacts on the foreign policy behaviours' of those states.' Countries such as China seek to shape the norm to accommodate 'their own perspectives on sovereignty and intervention' (Garwood-Gowers 2015: 320). Kenkel and Stefan (2016: 46) argue that, when dealing with R2P, emerging powers prefer 'to use state sovereignty to attenuate the unequal distribution of power in the international system.'

In a broader sense, Zaki Laidi (2012: 615) affirms that the main goal of the BRICS grouping is 'to erode Western hegemonic claims by protecting the principle which these claims are deemed to most threaten, namely the political sovereignty of states.' Or, to put 
it differently, it is 'a coalition of sovereign state defenders.' In the same vein, Kenkel (2016: 6) believes that non-Western states - and necessarily emerging powers - use the idea of traditional sovereignty (combined with non-intervention and territorial integrity) as a 'shield' to protect themselves from external interference. Andrew Hurrell (2013: 215) applies the term 'hard sovereignty' to qualify emerging powers like Brazil, China and India. This becomes even clearer when the IR scholarship evaluates humanitarian intervention practices (Morris 2013: 1279).

In general, it can be said that 'the discussion about R2P today continues to be largely seen in the context of a pro-interventionist Global North and a pro-sovereignty Global South' (Stuenkel 2014: 11). Therefore, most of the argument describes actions to reinforce Westphalian norms.

Some complementary interpretations emphasise other possible motivations. For example, there is the idea that these states want to shape the norm, since they do not believe that the use of force is the best course of action to solve humanitarian crises, or because they suspect that the humanitarian rhetoric may be used as an excuse to interfere in the domestic affairs of other states (Stuenkel 2014; Thakur 2013).

Although these arguments are not explicitly based on rigid sovereignty, they can be easily accommodated into it. In very broad terms, emerging powers are acting to reinforce their state-centric preferences. From a constructivist perspective, this would be an identity-driven process (Katzenstein et al 1996).

\section{Pluralist vision and the R2P norm-shaping process}

According to Edward Newman (2013), the vague commitment around R2P actually corresponds to an attempt to bolster Westphalian norms. This would be the position of the majority of non-Western states - notably the emerging powers. Newman argues that this serves to reaffirm a pluralist worldview. Despite exceptional circumstances, R2P is part of a pluralist international society focused on sovereignty and non-intervention (Newman 2016: 42).

For the English School of IR, a pluralist society is characterised by two basic features: firstly, it is an association composed of various political authorities based on values of sovereign equality, territorial integrity and non-intervention; secondly, it is also based on the idea that the domestic affairs of states are their own concerns; thus, citizens are free to organise their societies in line with their specific values (Jackson 2000: 178-179).

Pluralism is both an empirical view and a normative conception. It is empirical in the sense that it seeks to identify the main norms and institutions shared by states - which emerged from the Peace of Westphalia but evolved during the nineteenth and twentieth centuries when international society was expanding (Bull 1977). It is also normative ${ }^{2}$, since the authors of the School see its guidelines as essential understandings for the maintenance of international order.

By arguing that emerging powers put too much weight on sovereignty, norms scholars are claiming, in other words, that these states defend the pluralist structure of internation- 
al society. To the constructivist approach, when states engage in normative framing, they want to ensure that international norms fit their social identities ( $\mathrm{Pu}$ 2012: 349). Thus, it can be said that the pluralist elements of international society are also identity features of emerging powers. Roy Allison $(2013,2015)$ calls these countries 'pluralist states.'

Hence, it is possible to see the English School conception of pluralism through the constructivist lens. The Westphalian normative elements are the result of centuries of interstate relations. Bull (1977) points out that these norms, rules and institutions were created and diffused by the West throughout the world. Many of them - particularly the institution of sovereignty - became constitutive of states' identities (Wendt 1999). Considering that elements that constitute the identities of states are also responsible for guiding their actions (Wendt 1999; Katzenstein et al 1996), then the pluralist normative structure embodied by states also influences their external behaviour ${ }^{3}$. The combination of constructivism and the English School may offer an interesting interpretative device to understand the behaviour of emerging powers with regard to R2P.

Finally, it is necessary to note that pluralism is not restricted to sovereignty. In fact, it deals with a larger set of aspects posed by the theory - this is especially the case for what English School authors call institutions (Buzan 2004). These elements may serve to guide analysis using the School's framework.

But what exactly is pluralism? Robert Jackson (2000: 179) says that the concept of pluralism, brought by English School authors, comes from classical political science and legal theory:

They [English School authors] use the term in this original meaning in legal and political theory. They refer to the territorial-jurisdictional pluralism of the society of states and the value-diversity that such a societas accommodates. Pluralism is thus an expression of the constitutional freedom of sovereign states and the wide variety of domestic values accommodated by those same states.

Accordingly, this type of pluralism cannot be misinterpreted as that of sociology, which in fact claims the opposite. Sociological pluralism carries the idea that other forms of organisations other than states - such as intergovernmental and non-governmental organisations, civil society, etc. - are very important actors in world politics. This understanding tends to reduce the role of states. The English School version, on the other hand, is grounded on the notion that states are the central actors in international society (Jackson 2000: 179).

In pluralism, values such as religion and ideology are seen as internal prerogatives; they cannot serve as justification for interference by other states. This would exclude from international relations the Western political ideology of democracy, as well as other universalist ideas, such as Muslim jihadism and imperialist and communist ideologies. Jackson (2000: 181-182) affirms that pluralism is the accommodation of the idea of human diversity within the institution of sovereignty. This institution is central since it provides a 
territorial space free from external interference, wherein its members have no constraints in selecting their favoured type of government.

Dunne and Wheeler (1996) point out that in the traditional view of the English School, the pluralist conception of international society is the one in which states agree on some minimum goals for international order, and the most important one is the reciprocal recognition of sovereignty and non-intervention. In this sense, for pluralist authors, the society of states is primarily focused on a procedural vision of common values. Among these minimal understandings, there is the need for coexistence.

In other words, the pluralist conception is associated with a) an idea of society centred on the importance of interstate consensus for the maintenance of international order, b) respect for diversity (pluralism) between states, and c) fragility of international norms. There is some consensus on certain aspects of international order, but this consensus is sensitive. Any attempt to enforce some idea of progress in a particular direction can damage this order (Williams 2015: 105).

Andrew Hurrell (2007: 47-48) summarises the main features of pluralism:

1. ' $[\mathrm{A}]$ strong version of sovereignty and the reciprocal commitment to non-intervention or to limited intervention; and for the centrality of the balance of power as a means of constraining the predations of the powerful';

2. 'Moral values should, so far as possible, be kept out of particular international institutions [...] [life will be less bad] if states try to put aside arguments about fundamental values or deep ideological commitments and instead concentrate on bargaining over limited interests';

3. ' $[\mathrm{T}]$ he sceptical pluralist is attracted to the idea that it might also be possible to develop a cross-cultural consensus over the minimal rules around which such a limited international society might be built.'

Wendt (2000: 295) implicitly put pluralism into a constructivist theoretical approach by speaking of what he calls Westphalian culture. This culture, which has been internalised by states in a process of international socialisation, gives states the exclusive right to engage as actors in international politics. Thus, he argues that Westphalian states are 'individuals who do not appreciate the ways in which they depend on each other for their identity, being instead 'jealous' of their sovereignty and eager to make their own way in the world' (Wendt 2000: 295).

Contrary to pluralism, there is the view that international society is in a process of change - or could be modified, in a normative sense - into a form called solidarism. Solidarism is seen as a kind of extension of this society, not its transformation into an international community ${ }^{4}$ (Dunne 2008: 9).

Like pluralism, solidarism also turns its attention to values, norms and institutions shared by states, but in a more profound way - in contrast to the minimalist perspective of pluralism. According to Hurrell (2007: 58), there are several ways to grasp solidarism. For some, it means the possibility of imposing international norms and the use of force on behalf of the international society; for others, it would be a normative construction 
focused on individuals rather than states, or could be understood as the intensification both qualitative and quantitative - of international institutionalisation.

Considering the use of force, it is worth noting what Nicholas Wheeler (2000: 39) points out as an essential trait of solidarism: the idea that governments are responsible for defending not only the fundamental rights of their own citizens but also those of individuals of foreign nations. In practice, this responsibility means being able to engage in military intervention to halt human rights violations abroad.

According to Hurrell (2007), contemporary international society is in a process of transition towards what he calls liberal solidarism (or liberal order). This is happening due to various aspects, such as:

1. the rise in the number of intergovernmental and non-governmental organisations, a phenomenon that challenges the pluralist idea of international society based on minimal rules;

2. the transformation and the expansion of international law, characterised by the growth of international courts and dispute settlement bodies, the increasing number of international treaties, and the enlargement of the content that international law covers;

3. the improvement of global governance and the growing demands for compliance with international norms and rules. This would involve normative expansion with regard to different matters, notably economics, but also others such as environment, human rights and democracy. Sometimes the norms related to these issues are externally imposed, which is called coercive solidarism.

These are aspects of the international society that stem from the pressure of Western powers, a pressure which was more striking in two periods: post-1945 and post-1990. These two moments intensified the rise of liberal international order (Hurrell 2007).

Nonetheless, Hurrell (2016) pointed out later that contemporary international society cannot yet be perceived as the confirmation of liberal solidarism. Rather, it is a complex, changing society with relevant points of contention. It is marked by strong post-Westphalian characteristics, but still with several challenges coming from classic Westphalian features. And according to Hurrell, these tensions occur largely because of the engagement of emerging powers. These states are committed to the idea of returning to the Westphalian normative core, an understanding of an international society centred almost exclusively on the states themselves (Hurrell 2016: 09).

By using the English School's analytical framework, Barry Buzan (2004) listed the main institutions of contemporary international society. The list is useful in identifying which are the pluralist institutions and which are the solidarist ones (Table 1).

According to Buzan, the classical pluralist institutions are sovereignty, territoriality, diplomacy, great power management and international law. Issues such as human rights (especially international human rights law), democracy, popular sovereignty, and - particularly for this work - humanitarian intervention are, in turn, solidarist institutions (see the table below) (Buzan 2004: 187-188). 
Table 1 - Institutions of international society

\begin{tabular}{|c|c|c|}
\hline Primary institutions & & Secondary institutions \\
\hline Master & Derivative & (examples of) \\
\hline Sovereignty & $\begin{array}{l}\text { Non-intervention } \\
\text { International law }\end{array}$ & $\begin{array}{l}\text { UN General Assembly, most } \\
\text { regimes, international courts, } \\
\text { some PKOs }\end{array}$ \\
\hline $\begin{array}{l}\text { Territoriality } \\
\text { Diplomacy }\end{array}$ & $\begin{array}{l}\text { Boundaries } \\
\text { Bilateralism } \\
\text { Multilateralism }\end{array}$ & $\begin{array}{l}\text { Embassies, United Nations } \\
\text { Conferences }\end{array}$ \\
\hline $\begin{array}{l}\text { Great power } \\
\text { management }\end{array}$ & $\begin{array}{l}\text { Alliances } \\
\text { Balance of power } \\
\text { War }\end{array}$ & $\begin{array}{l}\text { Most IGOs, regimes, NATO } \\
\text { UN Security Council }\end{array}$ \\
\hline Equality of people & $\begin{array}{l}\text { Human rights } \\
\text { Humanitarian intervention }\end{array}$ & Human Rights Council \\
\hline Market & $\begin{array}{l}\text { Trade liberalisation } \\
\text { Finance liberalisation }\end{array}$ & GATT/WTO, IBRD, IMF \\
\hline Nationalism & $\begin{array}{l}\text { Hegemonic stability } \\
\text { Self-determination } \\
\text { Popular sovereignty } \\
\text { Democracy }\end{array}$ & Some PKOs \\
\hline Environmental stewardship & $\begin{array}{l}\text { Species survival } \\
\text { Climate stability }\end{array}$ & Environmental regimes \\
\hline
\end{tabular}

Source: Buzan (2004: 187)

Sovereignty is the core institution of pluralism (associated with the derived institution of non-intervention) (Jackson 2000; Hurrell 2007; Williams 2015; Dunne 2008). States are the de facto dominant actors (Buzan 2004: 46). This is also closely linked to the principle of territorial integrity (territoriality, Table 1).

In a pluralist conception, international law is conceived as a traditional or classical version. It corresponds basically to negative, rather than positive, obligations - it aims to restrict conduct, not to impose actions. 'International law is universally recognized and accepted because its norms are minimal in what they demand of sovereign states' (Jackson 2000: 417). The pluralist vision 'seeks not to burden international law with a weight it cannot carry' (Bull 1966: 71-72).

Particularly, proactive actions focusing on protecting human rights do not fit into the pluralist vision, considering that states do not share the same values. The only group of states that have a common culture with regard to human rights are the Western states:

[T] he world of states generally is not prepared, at least not yet, to accept positive international norms that apply to internal affairs and domestic governance. Only some states are prepared to do that. [...] [T] hey [the Western states] agree to be democracies and to protect human rights in their domestic jurisdictions. But beyond West that is not the case; most states [...] have only declared their intention to do that, for example, by being signatories to international human rights covenants [...]. [T] hat does not involve the surrender of state 
sovereignty, nor does it signal any abandonment of the doctrine of non-intervention (Jackson 2000: 417-418).

As for diplomacy, it is seen as a kind of understanding between states that do not pose threats to sovereignty. It is also associated with interstate multilateralism, based on intergovernmental institutions and interstate forums, such as the UN General Assembly. International intergovernmental organisations are regarded as auxiliary agencies; they play a functional role (Jackson 2000: 106). International civil society is protected by the states. Non-governmental organisations, in particular, are only subsidiary bodies, which depend on peace and order created by states to act internationally (Jackson 2000: 110).

Great power management is currently represented by the UN Security Council. There is the idea that, due to their relative superior material capabilities, great powers must assume responsibilities to preserve order, and should solve disputes, whenever possible, through mutual consensus (Linklater and Suganami 2006: 243). They are the guardians of international peace and security, the only actors capable of regulating the use of force. In this sense, unilateralism by states is strongly condemned.

By placing the emerging powers into the English School's theoretical framework, it is possible to infer that, because of sharing a kind of neo-Westphalian commitment focused on sovereignty and the principle of non-intervention (Cooper and Flemes 2013: 952), they have a pluralist view of international relations. This view has implications for how these states deal with R2P. They seek to adjust the norm to pluralist understandings, which makes it possible to consider them pluralist states. Roy Allison (2015: 1) sees pluralist states as follows:

Pluralist states adopt a traditionalist interpretation of sovereignty, seeking to restrict extra-territorial 'intrusion' in the domestic political and judicial affairs of states; it is very much a territorialized view of sovereignty. Such states tend towards a restrictive interpretation of the UN Charter, which is frequently cited as providing the legal basis for this stance. Pluralist states acknowledge that evolving international norms, including the international human rights agenda, have eroded 'hard' sovereignty, but seek to limit this process. They are adamant that unconsolidated international norms, which have not been codified and generally acknowledged in the canon of customary international law have no legal force and create no legal obligation.

More precisely, in seeking to reinforce the idea of traditional sovereignty around R2P, states such as Brazil, China and India are acting as pluralist norm-shapers: states that engage as norm-shapers in order to frame norms into the pluralist precepts of international society. The next section presents a brief example of norm-shaper engagement by analysing the Chinese case of Responsible Protection. 


\section{China as a pluralist norm-shaper: a brief analysis}

The most recent challenges to $\mathrm{R} 2 \mathrm{P}$ came from the Libyan and Syrian cases. The current emerging powers' engagement to shape the norm is, in many aspects, driven by these two events. It was due to the first episode that the Brazilian Minister of Foreign Affairs at the time, Antonio Patriota, launched the document 'Responsibility while Protecting: Elements for the development and promotion of a concept' (Patriota 2011). Brazilian action, as seen, came to be classified as a norm-shaper's behaviour.

Like Brazil, following the aftermath of the Libya intervention and the attempts to intervene in Syria, China also introduced a concept aimed to shape R2P. It was the idea launched by the China Institute of International Studies - and backed by the Chinese government - called 'Responsible Protection' (2012). The Chinese case is particularly emblematic not only because it is one of the most engaged states in shaping the norm (as presented in previous sections), but also because 'its ambition to become an international norm-shaper in various international settings has emerged as an openly assumed foreign policy goal' (Lang 2017: 331). China started to be regarded as a kind of 'revisionist stakeholder' (Zhao 2018). This section focuses on RP concept analysis, which is considered the main initiative posed by the Chinese to shape R2P.

Responsible Protection (CIIS 2012) was signed by Ruan Zongze, a former Chinese diplomat and currently vice President of CIIS. The paper sought to fulfil two central goals: a specific one, the goal of defending Beijing's stance on the conflict in Syria; and another general one, the goal of establishing more comprehensive guidelines related to R2P (Garwoods-Gowers 2016). This proposal is understood as a semi-official document - differing from $\mathrm{RwP}$ in this sense. Yet it was regarded as containing the essence of the Chinese vision for R2P. Apart from the fact that the think tank which created it is a sort of informal branch of the Chinese Ministry of Foreign Affairs ${ }^{5}$ (often considered a bearer of Chinese external thinking), the idea of responsible protection has become strategically used in official statements made by China since its inception (Garwood-Gowers 2016).

Before dealing specifically with the central directives offered to shape the norm, the document presents arguments to criticise the Western powers' external actions -focusing on the USA. The cases of Libya and Syria are considered paradigmatic. In this part of the argument, China's pluralist view is already clear. Sovereignty is quoted several times. Characteristic features of Chinese pluralism are declarations such as the idea that ' $\mathrm{t}] \mathrm{he}$ implementation of R2P should not contravene the principle of state sovereignty and the principle of non-interference of internal affairs' (CIIS 2012).

China's view on sovereignty and non-intervention is put forward as stemming from the basic legal framework that governs the international order. For instance, when speaking of the UN Charter, a pluralist interpretation of international law is noted:

R2P could be abusively employed to change the state power of a country, which contradicts the purposes of the UN Charter and the principles of state sovereignty and non-interference in other's inter- 
nal affairs prescribed in the Charter, and hence its legality and justness are questioned (CIIS 2012).

Other important features of pluralism - respect for diversity and non-intervention - are inferred from the document when identifying criticism of actions aimed at regime change. Hence, the Libya intervention is understood as 'a synonym of 'regime change' and constituted severe challenges to the traditional concept of 'state sovereignty' and such principles as non interference in other's internal affairs' (CIIS 2012). Particularly with regard to resolution 1973, which was used to justify NATO's action, the document claims that the term 'civilian protection' in the resolution 'was alienated into a strategic attempt at realizing "regime change" in Libya' (CIIS 2012).

In short, arguments related to regime change, military intervention and sovereignty summarise the Chinese pluralist view of international order:

Should "new interventionism" with use of force at every turn as well as regime change at the core and be allowed to grow and spread unchecked, the basic norms governing international relations would be severely undermined and the developing countries would be deprived of their legitimate rights of development and security (CIIS 2012).

The pluralism that the Chinese insist on showing is an understanding shared with the other BRICS members:

The Sanya Declaration issued in April 2011 at the Third BRICS Leaders Meeting pointed out: "We share the principle that the use of force should be avoided. We maintain that the independence, sovereignty, unity and territorial integrity of each nation should be respected. [...] We are of the view that all the parties should solve their differences through peaceful means and dialogue [...]” (CIIS 2012).

RP concept invokes what China understands as established elements of R2P. Four normative aspects are considered essential to interpret the norm:

1. state-centrism: 'The government of a given state bears the primary responsibility for protecting its citizens' (CIIS 2012);

2. limited normative scope: 'The concept of R2P applies only to the four international crimes of genocide, war crimes, ethnic cleansing, and crimes against humanity; in other words, only when the four crimes that grossly violate international law are committed and the government of a given state is unwilling or unable to exercise the right to protect its civilians will R2P be invoked' (CIIS 2012);

3. proportionality: 'To execute the responsibility to protect, the international community may only make proportionate intervention' (CIIS 2012). 
4. the need for adequate authorisation: 'UN Security Council authorization must be acquired if coercive force or military force is to be used' (CIIS 2012).

All these normative understandings highlighted by RP can be interpreted as the pluralist conceptions pointed out in the previous sections. By focusing on the notion that governments have the 'primary responsibility', RP shows the view that states should be the main actors in international society (Jackson 2000). The limited normative scope is associated with the pluralist idea that international society should be governed by 'minimal rules' (Hurrell 2007). Proportionality is related to limited intervention (Hurrell 2007). Finally, asserting the need for UNSC authorisation, in other words, highlights that security matters should be managed by the great powers - a primary institution (see Table 1).

Additionally, the document emphasises that following these four basic requirements means exercising R2P under international law. By international law, China means a legal normative structure where sovereignty is the ordering principle.

Later, RP offers its central guidelines for R2P, along with the justifications for using them. The table below respectively presents the guidelines and shows problems to be avoided by following these prescriptions.

Table 2

\begin{tabular}{ll}
\hline Guidelines & Problems to be avoided \\
\hline $\begin{array}{l}\text { To implement actions exclusively aimed at } \\
\text { protecting civilians }\end{array}$ & Actions motivated by other political intentions \\
\hline Intervention legitimately (legally) authorised & $\begin{array}{l}\text { Actions without appropriate authorisation of the } \\
\text { Security Council }\end{array}$ \\
\hline To exhaust political and diplomatic means & $\begin{array}{l}\text { Excessive use of coercive measures (which causes } \\
\text { more harm than good) }\end{array}$ \\
\hline To define the purpose of intervention precisely & \begin{tabular}{l} 
Using R2P to overthrow governments \\
\hline $\begin{array}{l}\text { Intervenors should participate in the post- } \\
\text { intervention reconstruction process }\end{array}$
\end{tabular} \\
\hline $\begin{array}{l}\text { Intervention without any further responsibility } \\
\text { ('smash and go') } \\
\text { mechanisms ex post factum }\end{array}$ & $\begin{array}{l}\text { Actions without any supervision (whether during or } \\
\text { after the military operation) }\end{array}$ \\
\hline
\end{tabular}

Source: Created by the author based on the RP document (CIIS 2012).

Taking into account Table 2, it can be seen that RP is a document designed to shape a norm based on pluralist conceptions. Apart from the fact that all these guidelines imply devices to protect traditional sovereignty, they can also be associated with other pluralist elements. For instance, legal authorisation (guideline 2) makes reference to primary institutions such as great power management and international law; prioritising diplomacy and peaceful means (guideline 3 ) is directly related to the primary institution of diplomacy (see Table 1); and guideline 4 is an expression of limited intervention and minimal rules (Hurrell 2007). 
It is instructive to note that several of these concerns are in line with what was proposed by Brazil in the Responsibility while Protecting concept. Notably, the Brazilian proposal also includes issues such as concern about proportional actions, the need for Security Council authorisation for any coercive measure, human concern with this kind of intervention, and the question of accountability when dealing with military operations (UN 2011).

In 2016, China demonstrated the strength of its vision at the UN General Assembly Thematic Panel Discussion focused on evaluating the 'Ten Years of Responsibility to Protect.' In the statement, the Chinese representative was consistent with the ideas presented in RP. The speech was structured in three main points, which direct the concept rationale.

In the first point, China reaffirms its state-centric view that primary responsibility lies with the states. Moreover, it emphasises that '[the international community] cannot violate respect for sovereignty by providing interference in internal affairs.' Sovereignty and non-interference are considered 'core principles as contained in the UN Charter.' Hence, similar to RP, the Chinese begin the 2016 statement using fundamental pluralist baselines (China 2016): state-centrism, sovereignty and non-intervention.

In the second point - also in line with Responsible Protection - they highlight the idea of limited normative scope. Thus, for China, R2P 'should be applied to four types of crimes. It would not allow expansion and wilful interpretation that would be used as a pretext for military interference in others' internal affairs' (China 2016: 1).

Finally, in the third point, the Chinese delegation focused on weakening the use of force as a core element of the norm. In this respect, it is reaffirmed that prevention, peaceful resolution of conflicts, and diplomacy should guide actions to implement R2P (China 2016).

The ideas posed by China's RP concept were also used to shape R2P at the Informal Interactive Dialogue on the Responsibility to Protect - a UN informal forum specifically created to advance the norm. Considering the statements released from 2009 until $2017^{6}$, it can be seen that Beijing stressed some of the RP's guidelines directly or indirectly in almost all of them. Some of these understandings were stated even before 2012 when the CIIS launched the Responsible Protection concept, which means that the ideas presented by the concept were already part of the Chinese view.

The first three guidelines identified in Table 2 were found in all the statements evaluated. Guideline 1 (implementing actions exclusively aimed at protecting civilians) emerges for instance when China stresses that R2P should be limited to the four crimes (genocide, crimes against humanity, ethnic cleansing and war crimes); guideline 2 (legal authorisation) normally appears when the Chinese affirm the need for observing the UN Charter; and guideline 3 (exhausting peaceful means) is found when the need to prioritise diplomacy, dialogue and peaceful measures is emphasised (see China 2009, 2011, 2012, 2013, 2014, 2015, 2016, 2017). Guidelines 4, 5 and 6 are randomly presented in one or another speech $^{7}$.

In summary, China seems to be an enlightening example of a pluralist norm-shaper when engaging with R2P. Beijing's central concerns with regard to the norm highlight 
this attitude. Particularly concerning the use of force, if the military intervention has become an option legitimately accepted by international society, Chinese engagement seeks to make this kind of action an alternative to be used in highly exceptional circumstances (China 2016).

This section intended to give a brief analysis to illustrate the theoretical argumentation presented in the previous parts of this article. However, an in-depth empirical investigation of China - as well as comparative work with other emerging powers - may reinforce these findings. ${ }^{8}$

\section{Conclusion}

In studies of IR, classifying certain states as only takers or rejecters with regard to normative dynamics is proving inadequate. Literature on norms points out that agency needs to be put on the agenda. Thus, around the discussions about the Responsibility to Protect, scholars have been developing the notion that some states are actually norm-shapers. Firstly, this essay sought to understand who these states are and how they act; then, it offered a theoretical framework aiming to evaluate the norm-shaper's behaviour.

Considering especially R2P, this article detailed the fact that the norm-shaper's behaviour is attributed, above all, to the emerging powers, countries - like Brazil, China and India - that act to adjust elements of the norm. The first two acquired more evidence because they launched proposals that aimed to establish guidelines for R2P.

After identifying these actors, the essay showed what kind of norm-shapers they are. Initially, it was verified what the main features found in literature are that characterise a norm-shaper. Emphasis was placed on studies intended to understand the emerging powers' behaviour in relation to R2P. The majority of these works brings the general idea that these powers are committed to preserving the traditional vision of sovereignty around the norm.

Specifically, this essay sought to evaluate how a reading of this engagement of the emerging powers could be understood by the theoretical approach of the English School of IR, along with elements present in the constructivist approach to social norms. In particular, it sought to evaluate how the emerging powers' engagement could be interpreted by the School's theoretical framework, combined with the constructivist approach to social norms. From this analysis, a more comprehensive theoretical concept was offered, which could provide a way of investigating the norm-shaper's behaviour in a more detailed manner.

The article then focused on what is called pluralism by authors of the School. As discussed throughout the essay, pluralism deals with a specific type of international society, one that adopts the basic structures of the Peace of Westphalia. It is also a normative understanding, in the sense that some scholars affirm that it is the most adequate arrangement for the maintenance of international order. 
A pluralist society is one that agrees upon minimal norms and rules for the maintenance of international order. In it, sovereign equality, non-intervention and territorial integrity are structural elements. It is in opposition to the so-called solidarist international society.

As presented by this article, there is a part of the literature on norms in IR which understands that contemporary international society, although it is not already solidarist, has strong features that show that it seems to be moving in this direction. It appears to be aimed at a specific solidarism: liberal solidarism (see Hurrell 2007). The international structure leans towards liberal values, because, among other aspects, the Western powers are the actors with the greatest power to influence the international normative arrangement and are therefore those that guide its reconfiguration.

In some respects, emerging powers have been adapting well to this process. For instance, they have increased their participation in international organisations and accepted greater regulation through international treaties. Nevertheless, the challenge becomes much greater in dealing with more sensitive matters to sovereignty, as in the case of the external imposition of human rights based on Western values.

The use of force for the protection of civilians in foreign states, when their governments do not authorise operations (often being the main violators) is classified as coercive solidarism (Hurrell 2007). This kind of action undermines the traditional idea of sovereignty. Emerging powers, as the more powerful representatives of the global South - a group who historically suffered the most from external interference - assumed the function of containing this process. In relation to $\mathrm{R} 2 \mathrm{P}$, these states do so not by rejecting the norm, but by shaping it so that it becomes consistent with pluralist precepts. Because of that, they were conceptualised here as pluralist norm-shapers.

At the end of the article, a brief case study was used to show how these theoretical constructions can be applied in qualitative analysis. It evaluated the case of the Chinese proposal called Responsible Protection. Therefore, in addition to introducing the concept of pluralist norm-shaper, this article also offered a conceptual framework that can be used to provide categories in empirical studies for investigating the norm-shaper's behaviour. A good procedure for future studies would be to use pluralist institutions as theoretical categories in qualitative content analysis.

In sum, the essay revealed that the English School can serve as an appropriate guide to normative studies in IR, especially when combined with other theories - as has been done here with the constructivist approach to social norms. This is a promising direction for future research.

\section{Notes}

1 Here we have the idea that international society is characterised by a liberal order, so structure pressure reflects this order. For more on the subject see Hurrell (2007).

2 Here the normative adjective is different from the one used previously, when employing it to refer to international norms. Usually, the normative theoretical approach intends to go beyond explaining social relations. It seeks to be propositive, asking how we should behave in international politics (see Frost 1994). 
3 As Wendt (1999: 286) put it, the great durability of what he calls the Westphalian culture suggests that its norms have been deeply internalised by the states.

4 As Bull (1977: 24) puts it, the idea of international community is a Kantian view that argues that the essential of international politics lies 'in the transnational social bonds that link the individual human beings who are subjects or citizens of states.' According to this view, 'international relations is only apparently the relationship among states' but it is 'really among all men in the community of mankind.' This is a potential relationship that 'when it comes into being will sweep the system of states into limbo.'

5 It employs several former diplomats, such as Ruan Zongze, the academic who signed the document.

6 All these documents are available at the International Coalition for Responsibility to Protect's (IRtoP) website. From 2009 to 2017, only the 2010 statement was not available on the ICRtoP website.

7 It is important to note than some of the annual meetings are thematic, although not mentioning a specific guideline does not mean that it is less important. The absence can be due to the fact that the directive may not be relevant to the thematic under discussion.

8 An example of this kind of approach is the recent work of Ribeiro, Medeiros and Leite (forthcoming). The authors used a systematic empirical evaluation to assess the Chinese engagement with regard to R2P and its coherence with the pluralist vision. Using Qualitative Content Analysis methodology to evaluate China's attitude in different forums, they identified how China applies normative prescriptions to shape R2P. Just to mention two of them, the authors identified that the Chinese applied a prescription called 'respect sovereignty and non-intervention' in $81.5 \%$ of the statements evaluated and that the prescription 'respect territorial integrity' appeared in 53\% of them (Ribeiro, Medeiros and Leite, forthcoming).

\section{References}

Allison, Roy. 2015. 'Contested understandings of sovereignty, the use of force and the wider international legal order: The political context.' European Leadership Network. At http://www.europeanleadershipnetwork.org/medialibrary/2016/04/05/6e134768/ELN\%20Narratives\%20Conference\%20-\%20Allison.pdf [Accessed on 3 January 2018].

2013. Russia, the West and Military Intervention. Oxford: Oxford University Press.

Benner, Thorsten. 2013. Brazil as a norm entrepreneur: The 'Responsibility while Protecting' initiative. Global Public Policy Institute Working Paper. Berlin: Global Public Policy Institute (GPPi). At https://www.gppi.net/media/Benner_2013_Working-Paper_Brazil-RWP.pdf [Accessed on 8 January 2018].

Bull, Hedley. 1966. 'The Grotian conception of International Society.' In Herbert Butterfield and Martin Wight (eds), Diplomatic Investigations. London: George Allen \& Unwin Ltd, pp. 51-73.

.1977. The Anarchical Society. New York: Columbia University Press.

Buzan, Barry. 2004. From International to World Society? English School Theory and the Social Structure of Globalisation. Cambridge: Cambridge University Press.

China. 2009. 'Statement by Ambassador Liu Zhenmin at the plenary session of the General Assembly on the question of "Responsibility to Protect." ICRtoP [online]. At http://responsibilitytoprotect. org/China\%20SC\%20June\%202009.pdf [Accessed on 10 December 2017].

. 2011. 'General Assembly Debate statement: China unofficial transcription from webcast.' Global Centre for the Responsibility to Protect [online]. At http://www.globalr2p.org/media/files/china1.pdf [Accessed on 10 December 2017].

2012. 'Statement delivered on behalf of the Permanent Mission of the People's Republic of China to the United Nations.' ICRtoP [online]. At http://responsibilitytoprotect.org/China\%20Statement\%20_Transcribed_.pdf [Accessed on 10 December 2017]. 
2013. 'Statement delivered on behalf of the Permanent Mission of the People's Republic to China to the United Nations.' ICRtoP [online]. At http://responsibilitytoprotect.org/China\%2013. pdf [Accessed on 10 December 2017].

2014. 'Statement by the People's Republic of China at the Informal Interactive Dialogue on R2P [Transcribed].' Global Centre for the Responsibility to Protect [online]. At http://www.globalr2p. org/media/files/peoples-republic-of-china.pdf [Accessed on 10 December 2017].

2015. 'Statement of the People's Republic of China - informal interactive dialogue on R2P, 8 September 2015.' ICRtoP [online]. At http://www.responsibilitytoprotect.org/china-1.pdf [Accessed on 10 December 2017].

2016. 'China's statement at the 2016 UN General Assembly Thematic Panel Discussion, From Commitment to Implementation: Ten Years of Responsibility to Protect [Transcribed].' ICRtoP [online]. At http://responsibilitytoprotect.org/Chinese\%20Statement.pdf [Accessed on 10 December 2017].

2017. 'Statement delivered by China - informal interactive dialogue on R2P, 6 September 2017 [UNOFFICIAL TRANSCRIPTION FROM WEBCAST].' ICRtoP [online]. At http://responsibilitytoprotect.org/2017-iid-china.pdf [Accessed on 10 May 2019].

China Institute of International Studies (CIIS). 2012. Responsible Protection (RP). At http://www. ciis.org.cn/english/2012-06/15/content_5090912.htm [Accessed on 10 December 2017].

Cooper, Andrew and Daniel Flemes. 2013. 'Foreign policy strategies of emerging powers in a multipolar world: An introductory review. Third World Quarterly 34 (6): 943-962.

Dunne, Tim. 2008. 'The English School.' In Christian Reus-Smit and Dunca Snidal (eds), The Oxford Handbook of International Relations. Oxford: Oxford University Press.

Finnemore, Martha and Kathryn Sikkink. 1998. 'International norm dynamics and political change.' International Organization 52 (4): 887-917.

Frost, Mervyn. 1994. 'The role of normative theory in IR.' Millennium 23 (1): 109-118.

Gardner, Phoebe. 2015. How have emerging states shaped the "Responsibility to Protect" debate regarding potential military intervention into Syria since April 2011? Master Thesis, Leiden University, The Netherlands. At https://openaccess.leidenuniv.nl/handle/1887/32232 [Accessed on 12 June 2017].

Garwood-Gowers, Andrew. 2015. 'R2P ten years after the World Summit: Explaining ongoing contestation over Pillar III.' Global Responsibility to Protect 7 (3-4): 300-324.

2016. 'China’s “Responsible Protection” concept: Reinterpreting the Responsibility to Protect (R2P) and military intervention for humanitarian purposes.' Asian Journal of International Law 6 (1): 89-118.

Hunt, Charles. 2016. 'Emerging powers and the responsibility to protect: Non-linear norm dynamics in complex international society'. Cambridge Review of International Affairs 29 (3): 1-21.

Hurrell, Andrew. 2013. 'Narratives of emergence: Rising powers and the end of the Third World?' Brazilian Journal of Political Economy 33 (2): 203-221

2007. On Global Order: Power, Values and Constitution of International Order. New York: Oxford.

2016. 'Towards the global study of International Relations.' Revista Brasileira de Política Internacional 59 (2): 1-18.

ICISS. 2001. The Responsibility to Protect. Canada: International Development Research Centre. 
Jackson, Robert. 2000. The Global Covenant: Human Conduct in a World of States. Oxford: Oxford University Press.

Jegat, Joseph. 2016. 'A norm-in-formation? An analysis of Brazil and China's normative engagement with the Responsibility to Protect.' Reponsibility to Protect Student Journal 2 (1).

Job, Brian. 2016. 'Evolution, retreat or rejection: Brazil's, India's and China's normative stances on R2P.' Cambridge Review of International Affairs 29 (3): 891-910.

Job, Brian and Anastasia Shesterinina. 2014. 'China as a global norm-shaper: Institutionalization and implementation of the Responsibility to Protect.' In A Betts and P Orchard (eds), Implementation and World Politics: How International Norms Change Practice. Oxford: Oxford University Press, pp. 124-143.

Katzenstein, Peter (ed). 1996. The Culture of National Security: Norms and Identity in World Politics. New York: Columbia University Press.

Kenkel, Kai. 2016. 'Rising powers and international intervention: The constraints on collective action.' In K Kenkel and P Cunliffe (eds), Brazil as Rising Power: Intervention Norms and the Contestation of Global Order. New York: Routledge, pp. 1-20.

Kenkel, Kai and Cristina Stefan. 2016. 'Brazil and the Responsibility while Protecting Initiative: Norms and the timing of diplomatic support.' Global Governance 22: 41-58.

Lang, Bertram. 2017. 'China's anti-graft campaign and international anti-corruption norms: Towards a new international anti-corruption order?' Crime Law Soc Change 70 (3): 331-347.

Linklater, Andrew and Hidemi Suganami. 2006. The English School of International Relations: A Contemporary Reassessment. Cambridge: Cambridge University Press.

Liu, Tiewa and Haibin Zhang. 2014. 'Debates in China about the responsibility to protect as a developing international norm: A general assessment.' Conflict, Security \& Development 14 (4): 403-442.

Laidi, Zaki. 2012. 'BRICS: Sovereignty power and weakness.' International Politics 49 (5): 614-632.

Morris, Justin. 2013. 'Libya and Syria: R2P and the spectre of the swinging pendulum.' International Affairs 89 (5): 1265-1283.

Newman, Edward. 2013. 'R2P: Implications for world order.' Global Responsibility to Protect 5: 235259.

Newman, Edward. 2016. 'What prospects for common humanity in a divided world? The scope for RtoP in a transitional international order.' International Politics 53 (1): 32-48.

Patriota, Antonio. 2011. 'Letter dated 9 November 2011 from the Permanent Representative of Brazil to the United Nations addressed to the Secretary-General.' At http://www.globalr2p.org/media/ files/concept-paper-_rwp.pdf [Accessed on 10 June 2019].

$\mathrm{Pu}$ Xiaoyu. 2012. 'Socialisation as a two-way process: Emerging powers and the diffusion of international norms.' The Chinese Journal of International Politics 5: 341-367.

Ribeiro, Mikelli, Marcelo Medeiros and Alexandre Leite. Forthcoming. 'China’s engagement with R2P: pluralist shaper?' Global Responsibility to Protect.

Stefan, Cristina. 2016. 'On non-Western norm shapers: Brazil and the Responsibility while Protecting. European Journal of International Security 2 (1): 88-110.

Tourinho, Marcos, Oliver Stuenkel and Sarah Brockmeier. 2015. 'Responsibility while Protecting: Reforming R2P implementation.' Global Society 30 (1): 134-150. 
Thakur, Ramesh. 2013. 'R2P after Libya and Syria: Engaging emerging powers.' The Washington Quarterly 36 (2): 61-76

UN. 2005. World Summit Outcome. A/60/ L.1. New York.

UN. 2011. 'A/66/151-S/2011/701: Letter Dated 9 November 2011 from the Permanent Representative of Brazil to the United Nations Addressed to the Secretary-General.' Security Council Report. At http://www.securitycouncilreport.org/atf/cf/\%7B65BFCF9B-6D27-4E9C-8CD3CF6E4FF96FF9\%7D/POC\%20S2011\%20701.pdf [Accessed on 10 June 2018].

Wheeler, Nicholas. 2000. Saving Strangers: Humanitarian Intervention in International Society. Oxford: Oxford University Press.

Welsh, Jennifer. 2013. 'Norm contestation and the Reponsibility to Protect.' Global Reponsibility to Protect 5: 365-396.

.2014. 'Implementing the "Responsibility to Protect": Catalyzing debate and building capacity.' In Alexander Betts and Phil Orchard (eds), Implementation and World Politics: How International Norms Change Practice. Oxford: Oxford University Press, pp. 124-143.

Wendt, Alexander. 1999. Social Theory of International Politics. New York: Cambridge University Press.

Williams, John. 2015. 'Pluralism, the English School and challenge of normative theory'. In Robert W Murray (ed), System, Society and the World: Exploring the English School of International Relations, 2nd edition. Bristol: E-International Relations, pp. 105-110.

Zhao, Suisheng. 2018. 'A revisionist stakeholder: China and the post-World War II world order' Journal of Contemporary China 27 (113): 643-658.

Zheng Chen. 2016. 'China and the responsibility to protect.' Journal of Contemporary China 25 (101): 686-700.

\section{Acknowlegments}

The author would like to thank Professor Jennifer Welsh for her insights with regard to the idea that emerging powers are norm-shapers engaged in preserving not only sovereignty but also pluralist understandings of international society. Professor Welsh supervised the author during his period as visiting Ph.D. at the European University Institute (2017).

\section{About the author}

Mikelli Marzzini L. A. Ribeiro is Professor of International Relations in the Political Science Department of Federal University of Pernambuco (Brazil). He was professor of Law in Bahia State University (Brazil) from 2013 until 2019, where he taught International Law. He holds a Ph.D. in Political Science from Federal University of Pernambuco (Brazil) and a Master's Degree in International Relations from Paraiba State University (Brazil). During his Ph.D., he was visiting researcher at the European University Institute (Italy) and at Leiden University (The Netherlands). He has published articles related to human rights, emerging powers' foreign policy and international institutions. His publications have focus especially on the Responsibility to Protect and humanitarian intervention. 


\section{R2P e os Modeladores de Normas Pluralistas}

Resumo: O R2P trouxe novos desafios para a pesquisa de normas nas Relações Internacionais, principalmente devido às ações das potências emergentes. Esses estados tiveram um comportamento complexo em relação à norma. Em vez de classificá-los como simples rejeitadores ou tomadores de normas, a literatura atual sobre normas em Relações Internacionais os classificou como formadores de normas. Em seu comportamento, as potências emergentes procurariam moldar a norma sob vários ângulos. Nesse sentido, surge a necessidade de enquadrar teoricamente esses tipos de engajamento. Este ensaio tem como objetivo analisar a ação de modeladores normativos através das lentes da Escola de Inglês de Relações Internacionais, combinada com o construtivismo. Depois de apresentar os modeladores de normas e caracterizá-los teoricamente, é introduzido um novo conceito, chamado modelador de normas pluralista.

Palavras-chave: Responsabilidade de Proteger; Escola Inglesa; potências emergentes; norm-shapers; pluralismo.

Received on 25 July 2019, and approved for publication on 6 January 2020. 